Tkachuk V.P., Sokolan K.S., Sokolan J.S.

Khmelnitskiy national university,

Khmelnitskiy, Ukraina

E-mail: tkachukv.p@gmail.com

\section{EQUILIBRATION OF SUGAR CENTRIFUGES BY METHOD OF AUTOMATIC BALANCING}

UDC 62-137

DOI: $10.31891 / 2079-1372-2019-91-1-14-20$

The article represents materials that illustrate operation principle of centrifuges for separation of massecuite strike on sugar refineries and methods of increasing reliability and performance quality of their operation are revealed in the article. Reasons of origin of centrifuge vibrations as a result of non-equilibrium during their operation are envisaged among other factors. Methods of vibration decreasing as a result of applying auto-balancing devices are offered and results of experimental researches on research stand are summarized.

Key words: rotor, imbalance, automatic balancing (self-balancing), auto balancing device (ABD), centrifuge.

Production of granulated sugar consists of following operations: feeding of the beet to factory and its cleaning from foreign matters (soil, sand, remainders of beet greens); cutting of roots in chippings and obtaining diffusive juice (beet processing department); cleaning from nonsugar using lime carbonate with consequential additional cleaning, concentration of the juice by evaporation up to the density of syrup (juice purification house); allotment of cane sugar from the syrup by crystallization, separation of granulated sugar from massecuite syrup, its drying and packing in containers [1]. After syrup boiling the product is called massecuite strike. Obtained massecuite strike is divided in Peeler Centrifuges into commercial granulated sugar and massecuite syrup (deflux), in which quantity of sugar is decreased on following stages of crystallization.

Temp of centrifuge process must provide relieving of massecuite mixer until the time of unloading massecuite strike from following vacuum apparatus. Herewith it is necessary to call attention to correspondence of actual time of the centrifuge process cycle to the time, indicated in centrifuge operation manual. If time of one full cycle is greater, power consumption is increased and electric motor of centrifuge can get out of order. It is observed in case of transfer from automatic to manual control, and also when cycle is shortened, when massecuite strike has big crystals and low viscosity of massecuite syrup. For normal operation of automated centrifuges it is necessary to maintain sugar crystalline content in massecuite strike within the limits of $50-55 \%$ and viscosity, providing its equal distribution order by the heights of rotor in such a way as to loading time would be 15 - 25 seconds.

Centrifuges are used for separation of liquid heterogeneous mixtures (suspensions and emulsions) into constituent elements. Separation process in centrifuges is carried out in the field of centrifugal forces with usage of complete septum or pseudoseptum. These septum (baffle plates) are made in cylindrical form, conical form or combined cylindrical-conical rotors, rotating under condition of high frequencies.

Most of all monolithic walls are carried out in sedimentation centrifuges. In them the separation of suspensions and emulsions is carried out by the principle of sedimentation, in other words action of gravity force is replaced by the action of centrifugal force.

In filtrating centrifuges rotor walls are perforated and only in several constructions they are monolithic. In monolithic walls removal of liquid phase is carried out through apertures in upper and lower bead rings. Separation process of suspensions in such centrifuges is carried out according to the principle of filtration of liquid phase through the layer of solid particles under the influence of centrifugal force, which value depends of acceleration of centrifugal field, created by rotor.

We turn our attention to the drawing of centrifuge $Ф П С$ - they are widely spreader in sugar refining industry of Ukrainian productions (fig. 1). Suspension feeding to distributing disk facilitates equal loading of the rotor. Form of the rotor is cylindrical-conical, its lower edge is connected with several ribs with thrust bush on the embankment. Unloading apertures between ribs during filtration process and the process of residues douching are closed by lifting cone. After centrifuging residues the cone ascends, rotating speed decreases and residues are dropped into the bowl. Necessary speed of rotor during self-unloading depends on the angle $\beta$ between rotor's axis and the edge of its conical part, and also friction coefficient $f$ between residues and walls. Particle with mass $m$ will move along the edge of the contour, if the difference between constituent of gravity force and centrifugal force $m \cdot g \cdot \cos \beta-m \cdot \omega^{2} \cdot R \cdot \sin \beta$ will be greater than friction force $f \cdot\left(m \cdot g \cdot \sin \beta+m \cdot \omega^{2} \cdot R \cdot \cos \beta\right)$. Therefore $\omega<\sqrt{\frac{g \cdot(1-f \cdot \operatorname{tg} \beta)}{R \cdot(f+\operatorname{tg} \beta)}}$, and condition for self-unloading is $f<1 / \operatorname{tg} \beta$, when $\omega=0$. 


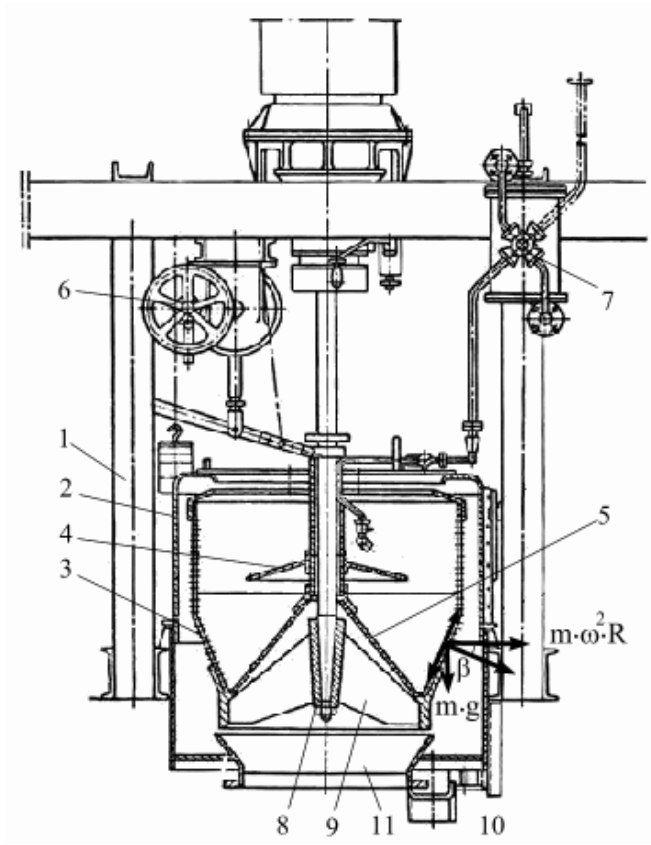

Fig. 1 - Centrifuge ФПС:

1 - body frame; 2 - housing; 3 - rotor; 4 - distributing disk;

5 - lifting body frame; 6 - lifting mechanism; 7 - collector;

8 - thrust bush; 9 - stiffening plate; 10,11 - unloading of molasses and sugar

In engineering practice for characterization of separation capability of centrifuges not value of acceleration of centrifugal field is used, but its relation to gravity acceleration. This relation is called separation coefficient:

$$
F_{r}=\omega^{2} R / g,
$$

where $\omega$ is angle rate of rotor rotation, $\mathrm{rad} / \mathrm{sec}$.

$$
\omega=\frac{\pi n}{30}
$$

$n$ - number of rotor rotations in one minute;

$R$ - radius of the rotor, $\mathrm{m}$;

$g$ - gravity acceleration, $\mathrm{m} / \mathrm{sec}^{2}$.

It worse noticing that the value of separation coefficient in occasionally operating centrifuges is not the same during whole cycle. It is minimal during acceleration and reaches its maximum during centrifuging process.

Nonequilibrium distribution of massecuite strike as a result of its low or increased viscosity along rotor's heights causes vibration of centrifuge during loading or during acceleration of the rotor and, subsequently, the level of noise is considerably increased.

In practice operating personnel of centrifuges often feels negative influence of noise and vibrations. Influence of vibration has negative influence on health, worsens general condition, decreases workforce productivity, and sometimes it even leads to occupational health problems, particularly hand-arm vibration syndrome (HAVS). According to the data of World Health Organization, increased levels of vibration and noise are prime factors in emergence of cardiovascular diseases of workers.

Methods of decreasing harmful vibrations from operating machines and mechanisms can be divided into two main groups:

1) supportd on decreasing the intensity of generating forces in the source of their origin;

2) vibration damping on the way of their distribution through bearing connections from the source to other machines and building structures (vibration damping).

In engineering practice oftentimes someone has to develop methods of vibration decreasing on the way of its distribution from vibration source. Effective abatement of harmful vibration method is passive vibration insulation when combined with using iso mounts (bearings with the effect of vibration damping). Usage of such bearings provides decreasing of transferring the dynamic force from machines to the support, and also vibrations decreasing that are transferred from the support to workplaces by placing springing elements between them (vibration isolation systems or shock dampers). Installation of the machine on elastic supports practically doesn't decrease vibration of machine itself, but it decreases vibration transferring to supporting structures and, subsequently, decreases vibration of workplaces. Active vibration isolation is also used. Additional power source is used for its activation. 
Vibration isolation system is made from steel springs, rubber and other materials. Combined subbermetal and spring-rubber vibration isolation systems and pneumorubber shock dampers, that use elastic properties of compressed air, are also applied.

Oscillations that are transferred to workplaces and building structures can be decreased by their installation on massive vibration isolating supports.

Constructively vibration isolating supports produced in the shape of reinforced concrete slab with acoustic junction along its perimeter, filled in with lightweight materials and assigned for prevention of direct transfer of oscillations from the foundation to building structures.

Track records concerning decreasing of vibrations of rotors with vertical rotation axis under conditions of variable disequilibrium during operation shows that effective method of decreasing vibrations is automatic balancing by applying hollow chamber, partially-field with solid and liquid actuating mediums.

Idea of self-balancing of centrifuges in sugar refining industry is not new. On present showing first ABD is ring type (fig. 2), offered by German engineer Albert Fesca from Berlin on March 26, 1872, when he received USA patent No. 125036 for ring type ABD, designed for quilibration of vertically located machine drum for sugar draining. Patent was reissued as patent US №7,455 Reissued, 2 Jan. 1877 (in some historical surveys of balancing technique this reissue is falsely assumed as primary patent, and date 02.01 .1877 - as the beginning of the history of passive auto-balancing technique). A. Fesca have offered to cover inside the drum on its shaft two and more rings of bigger and smaller diameters than the diameter of the shaft.

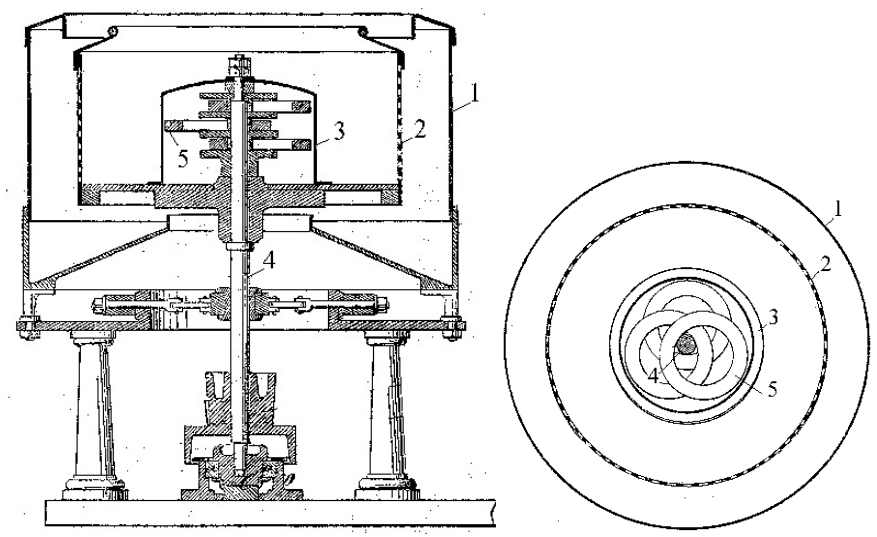

Fig. 2 - Ring ABD of A. Fesca (1872):

1 - machine for sugar draining; 2 - drum; 3 - ABD; 4 - shaft; 5 - ring

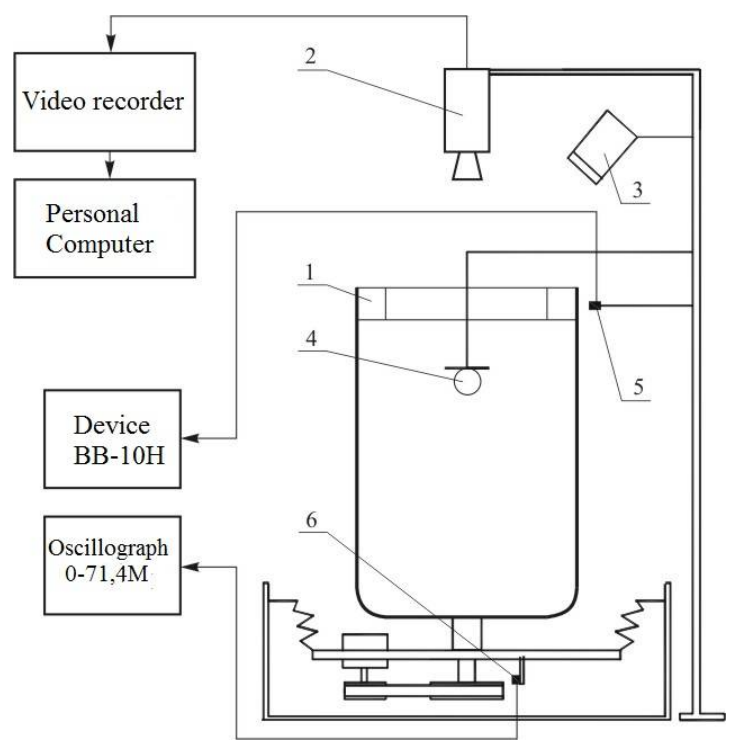

Fig. 3 - Schematic diagram for research of the mode of behavior of actuating mediums in ABD:

1 - ABD model; 2 - video camera;

3 -strobotac; 4 - incandescent-filament lamp;

5 - inductive sensor; 6 -indicating device of rotation 
Analysis of literature sources have shown that the theory of self-balancing is described in various works of native and foreign authors. All works assert that necessary condition of vibration decreasing by applying ABD is rotation of the rotor with frequency greater than first critical (resonance). Against this background constructions of modern $\mathrm{ABD}$ have additional devices, allowing actuating mediums to kick into gear only under condition of above resonance frequencies of rotor's rotation. It significantly complicates the construction of ABD and doesn't allow their widespread use.

Meanwhile authors in practice have found out that ABD can decrease vibrations both under conditions of above resonance and before resonance frequencies, and under the condition of resonance [4]. Experimental researches of possibilities for effective self-balancing of centrifuges by passive balance beams was carried out on test installation (fig. 3) with device that has rigid vertical shaft and in which body frame is rigidly fastened with the support. Rotor of the device is connected with body frame through the system of springs and can easily realize processional motion. Such construction is analogous to the construction of rotor in centrifuge.

Experimental model of ABD made of optically-transparent material, which provides to track in visual form or with the help of modern video recording devices operation of ABD on all operation modes was designed and made for research of liquid mode of behavior inside self-balancing device in precritical and postcritical rotor rotation zones in auto-balancing device.

$\mathrm{ABD}$ is a ring with outer diameter of $\varnothing 400 \mathrm{~mm}$, two concentric baffles with diameters of $\varnothing 300$ and $\varnothing 200 \mathrm{~mm}$ that create three concentric chambers for placing actuating mediums in them. Assembled representation of ABD experimental model is shown on figure 4.

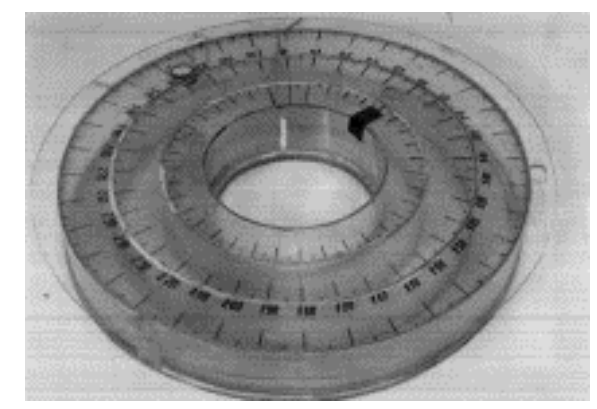

Fig. 4 - experimental model of ABD

All three chambers are hermetically isolated from each other that renders possible to indicate dependence of auto-balancing process on geometrical sizes of the chamber.

Method of high-speed video recording of the movement of actuating mediums using modern computer engineering and video technology was proposed for carrying out experimental researches of the operation of liquid ABD.

Research of the mode of behavior of actuating mediums inside ABD was carried out on specially designed bench that contains following facilities:

Video camera Panasonik 9000;

Video recorder Panasonik NC-HC 1000;

Personal computer of following configuration: processor - Celeron $2000 \mathrm{MГц,} \mathrm{motherboard} \mathrm{-} \mathrm{ASUS}$ P4S533, RAM - 512 Мб, video card - ATI Radeon 9000 (64 Мб), Winchester disk - WD80ВВ (80 Гб), sound card - ESS 1938 (16 Bit, PCI) compatible with Sound Blaster, TV Tuner - FlyTV Prime34 FM;

Light-beam recording oscillograph H071.4;

Strobotac CШ-1;

Movement metering device BB-10H;

Inductive displacement pickup;

Variable inductance transducer (indicating device of rotations).

Flow diagram of connection of facilities is shown on figure 3.

Strobotac CШ-1 synchronized with the signal of indicating device of rotor's rotations was used when carrying out previous researches of operating monitoring of actuating mediums position inside ABD.

Video camera was placed in vertical position above ABD along the rotation axis of ABD. Video recording of balancing process was carried out synchronically with the recording of rotor's vibrations.

Test data processing was carried out by applying comparison of video records with records on oscillographic recordings that gave possibility to determine location of resonance region on video records, and also value of rotation frequency for still frames that are being processed.

Methodology of researches conducting by applying high-speed video recording of ABD on vertical rotor consists of three stages: preparative, research of transient modes, research of stationary and quasistationary modes. 
1. Preparative stage includes:

- rotor's balancing with $\mathrm{ABD}$ in case of absence of actuating mediums inside ABD;

- selection of the value and location of artificial rotor imbalance;

- determination of optimal volume of process liquid in $\mathrm{ABD}$;

- determination of optimal illumination of ABD;

- determination of necessary motion speed of video tape;

- determination of the optimal location of video camera (selection of look-up angle and distance to $\mathrm{ABD})$

- test launching of whole system for cooperation adjustment of its separate parts.

Rotor balancing with experimental model of ABD in case of the absence of actuating mediums inside it was carried out by applying passing-by method of trial cargo under conditions of operating rotor rotation frequency.

Value of artificial rotor imbalance was determined on its operating rotation frequencies as follows: the mass of artificial rotor was stepwise increased in increments of 30 grams from the start to start and rotor vibrations level was measured.

Critical maximal value of the imbalance was considered to be that value, under conditions of which vibration amplitude reached $40 \mathrm{~mm}$ (higher values in current construction of the device lead to impacts of motional elements on body frame) or when electric drive is not able to increase rotations when passing through resonance of the system and rotor "hovers" at critical rotation frequency.

Determined upon criteria value of the mass of the imbalance, decreased by $30 \mathrm{~g}$ (value of one step) and which is $m=150 \mathrm{~g}$, was takes as reference value for follow-up researches.

For carrying out video recording, the visibility of automatic balancing process on all rotations of rotor was taken as the criterion of optimal volume of process fluid in ABD, in other words, when location of process fluid relatively to the location of artificial imbalance was clearly visible in the light of strobotac and on video tape. Determination of such volume values was carried out in an experimental way.

As a result of such researches received fluid volumes (colored fresh water) that was 400, 300 and $250 \mathrm{ml}$ for outer, medium and inside chambers of ABD respectively.

Special aspects of transient mode of rotor rotation with $\mathrm{ABD}$ (acceleration, running-out) are existence of angular acceleration that can effect on the movement (location) of actuating mediums.

Following methodology was offered and experimentally tested for research of actuating mediums movement in case of existence of angular acceleration:

Necessary imbalance is set on the rotor. Fluid is filled in ABD;

Electric current is gradually delivered to electric engine of the rotor and minimal voltage value $U_{0}$ is fixed (at this value rotor's movement begins);

Maximal voltage is feed to the drive of electric engine, by virtue of which rotor gather speed of indicated nominal rotation speed and value $U_{\text {ном }}$ is fixed;

Minimal voltage $U_{0}$ is feed to the drive of electric engine and its value changes leapingly to $U_{\text {ном }}$, herewith time $t_{0}$ when rotor reaches operating rotation frequencies that corresponds to maximal angular acceleration $\varepsilon_{\max }$;

The time, necessary for change of voltage from $U_{0}$ to $U_{\text {ном. }}$, that is feed to drive electric engine is calculated by approximation formula:

$$
t_{i}=\frac{\varepsilon_{\max }}{\varepsilon_{i}} \cdot t_{0}
$$

where $t_{i}$ - time interval of the change of voltage from $U_{0}$ to $U_{\text {нол }}$;

$\varepsilon_{i}-$ necessary value of rotor angular acceleration during i experiment.

Video camera starts operating synchronically with rotor and video facilities and the movement of actuating mediums inside $\mathrm{ABD}$ during the start under conditions of indicated angular acceleration $\varepsilon_{i}$ with hold time at operating rotation frequency during $10-15 \mathrm{~s}$ is recorded.

Resonance speed of rotor rotation is $\omega_{p}=56,5-63 \mathrm{rad} / \mathrm{sec}(540-600 \mathrm{rpm})$. For research of mode of behavior of actuating mediums inside $\mathrm{ABD}$ under conditions of before resonance, resonance and above resonance rotor rotation frequencies, rotor angular speed was set as $0,5 \omega_{p}$ and $0,75 \omega_{p}$ (before resonance zone), $\omega_{p}$ (resonance zone), 1,5 $\omega_{p}$ (above resonance zone). 
Video camera along with facilities were switched on after time $\Delta t=10-15 \mathrm{sec}$, when rotor heights was at indicated rotation frequency and when location of actuating mediums relatively to marks on ABD's body frame was stabilized.

Video recording at each of indicated rotation frequencies was carried out during 20 - 30 sec.

For the purpose of determination of the effectiveness of rotor automatic balancing method with vertical rotation axis of fluid the row of researches with change of artificial imbalance mass within the limits from $50 \mathrm{~g}$ to $250 \mathrm{~g}$ in increments of $50 \mathrm{~g}$ for different radius of chamber was carried out. Chambers were filled with fluid, $R=0,2 ; 0,15 ; 0,1 \mathrm{~m}$ and amount of fluid in the chamber was also changeable from $0 \mathrm{~g}$ to $350 \mathrm{~g}$ in increments of $50 \mathrm{~g}$. imbalances were located almost in plane of the location of ABD chamber. Researched range of rotor rotation speeds was $0 \mathrm{rad} / \mathrm{sec}-88 \mathrm{rad} / \mathrm{sec}$. For detailed researches of ABD operation the hold time in $5-10 \mathrm{sec}$ in before resonance, resonance and above resonance zones of rotor rotation were carried out. For each order the amplitude frequency response of oscillations of drum's upper edge was built. Preliminarily before the research the additional balancing of rotor of the device (wahing machine tank) by cargo passing-by method was carried out [5]. mental way.

Efficiency checking of fluid ABD operation was carried out in two ways: calculations and in experi-

For experimental checking of the influence of ABD parameters, particularly chamber's radius, on the effectiveness of balancing process, series of tests with cylindrical ABD chambers with the same heights $(50 \mathrm{~mm})$ and different radiuses $(200 \mathrm{~mm}, 150 \mathrm{~mm}, 100 \mathrm{~mm})$ was carries out. Record of vibrations of disbalanced rotor (3000 g·sm disbalance) was preliminarily carried out. In the following chambers of different radius were in turns filled with water (volume $150 \mathrm{ml}$ ) and record of vibrations of the system was carried out. Oscillation AFR of the upper edge of the drum under conditions of $3000 \mathrm{~g} \cdot \mathrm{sm}$ disblanace is represented by figure 5 , where AFR for cases with fluid in different chambers of ABD are shown for comparison.

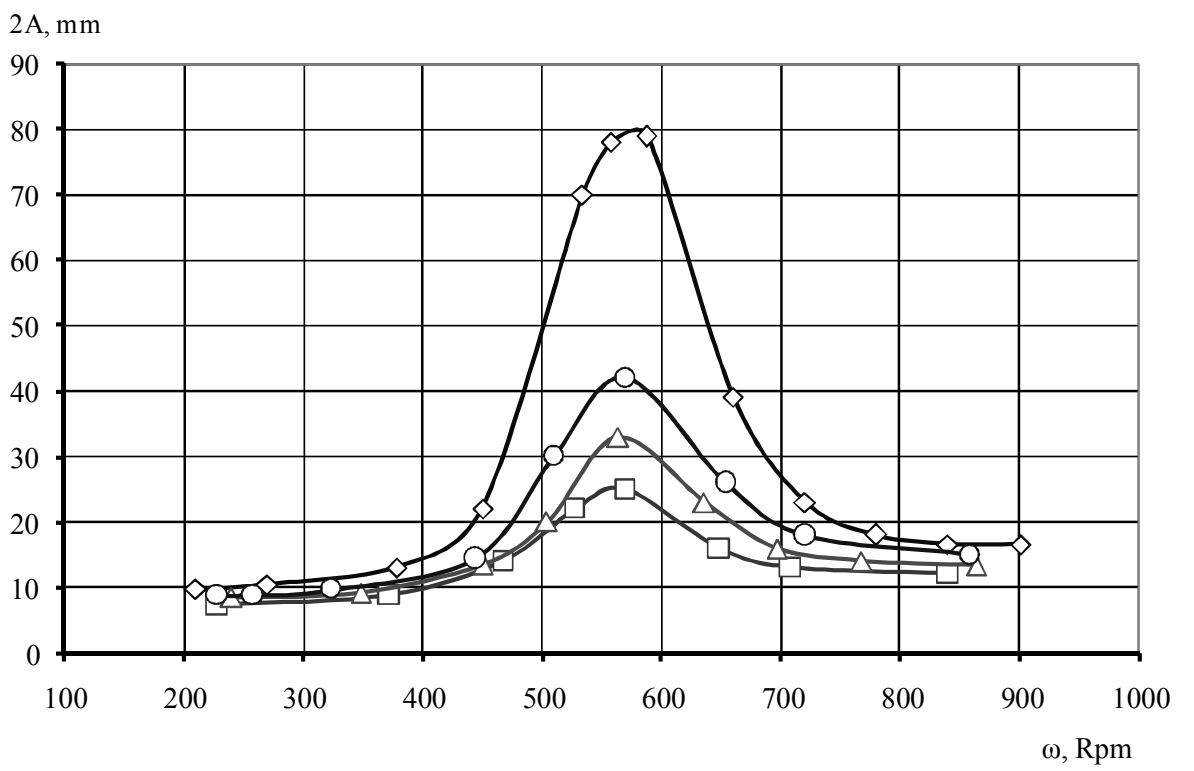

$$
\begin{aligned}
& \checkmark \text { without fluid inside cha mbers of ABD } \quad-\square-\text { with fluid cha mber of } 20 \mathrm{sm} \text { radius } \\
& \neg-\text { with fluid in chamber of } 15 \mathrm{sm} \text { radius } \quad-0-\text { with fluid in chamber of } 10 \text { sm radius }
\end{aligned}
$$

Fig. 5 - AFR of oscillation of upper edge

of the drum under conditions of $3000 \mathrm{~g} \cdot \mathrm{sm}$ disbalance

Calculation research results are proved correct by experimental (fig. 5), videlicet:

- when using ABD with fluid actuating mediums, the decreasing of rotor oscillatory amplitude along all rotation frequency range is observed;

- when mass and density of fluid are constant, value and location of imbalance, the increasing of correspondence between radius and height of $\mathrm{ABD}$ chamber leads to decreasing of rotor oscillation frequencies;

- the most significant balancing effect is reaches, when the value of fluid imbalance is close to the value of initial imbalance; balancing effect grows under conditions of approaching of operating speed to resonance one, that is expressed in facilitation of transferring through resonance and critical rotation frequencies. 


\section{Conclusions}

Experimental researches of the mode of behavior of actuating fluid inside ABD chamber using highspeed video recording and dynamical photography are carried out.

On the grounds of the results of experimental and theoretical researches, the construction of combines fluid-globular auto-balancing device was developed, using which allows decreasing rotor vibrations not less than in 2,5 times along whole rotation frequency range.

Similarity of construction diagram of experimental apparatus and centrifuge ФПН-125, used un sugar refining industry, suggests that application of auto-balancing method for vibration decreasing will be sufficiently effective on given types of centrifuges without applying significant changed in the construction.

\section{References}

1. Domaretckiy V.A. Technology of alimentary products. / V.A. Domaretckiy, M.V. Ostapchuk, A.I. Ukrainetc - K.: HУXT, 2003.- 569 p.

2. Goroshko A. Quality and Reliability of Technical Systems: Theory and Practice / A. Goroshko, V. Royzman, M. Zembytska // Ilona Drach, Vilen Royzman, Vitalii Tkachuk, Andrii Goroshko System Analysis of Automatic Balancing (Self-Balancing) Machine Rotors with Liquid Working Bodies on the Example of Drum Type Washing Machines // Volume 2, August 2018, pp. 26-60, ISBN 978-609-96036- 0-5 Published by JVE International Ltd. [Електрон. pecypc] / Book Series. JVE Journals - available at: https://www.jvejournals.com/bookseries

3. Cholovskiy R.G. Vibrations and auto-balancing of machinges with vertical rotation axis and changeable rotor imbalance: dissertation of candidate of science: 05.02.02 - 1999.

4. Roizman V.P. Differences of automatic balancing for rotors with horizontal and vertical rotation axes / V.P. Roizman, V.P. Tkachuk, I.V. Drach // Collection of scientific works B. Khmelnitskiy NAFSU, series: national defense and technical sciences - Khmelnitskiy, NAFSU, 2015. - p. 64-67.

5. Skubachevskiy G.S. Aviational gas-turbine engines. Calculations and constructions of details. / G.S. Skubachevskiy - M.: Mechanic engineering, 1974. - p. 266-269.

Ткачук В.П., Соколан Л.С., Соколан Ю.С. Врівноваження цукрових центрифуг мкетодом автоматичного балансування.

У статті викладено матеріали, які висвітлюють принцип роботи центрифуг для розділення утфелю на цукрових заводах та шляхи підвищення надійності і якості їх роботи. Нерівномірний розподіл утфелю внаслідок його низької або підвищеної в'язкості по висоті ротора викликає вібрацію центрифуги під час завантаження або при розгоні ротора i, як наслідок, суттєво підвищується рівень шуму. В інженерній практиці часто доводиться розробляти заходи щодо зменшення вібрацій на шляху іï поширення від джерела до суміжних машин. Зокрема розглянуто причини виникнення підвищених вібрацій центрифуг внаслідок незрівноваженості під час їх роботи. Запропоновано шляхи зниження вібрацій за рахунок застосування автобалансуючих пристроїв та наведено результати експериментальних досліджень на дослідному стенді. На підставі експериментальних і теоретичних досліджень розроблена конструкція комбінованого рідинно-кулькового автобалансуючого пристрою, застосування якого дозволяє знизити вібрації ротора не менше, ніж в 2,5 рази у всьому діапазоні частот обертання.

Ключові слова: ротор, дисбаланс, автоматичне балансування (балансування рідиною), автобалансуючий пристрій, центрифуга. 